\title{
Pengaruh dana pihak ketiga, kecukupan modal dan penyaluran kredit terhadap profitabilitas bank
}

\author{
Sudarmin Parenrengi \\ Fakultas Ekonomi dan Bisnis, Universitas Pancasila, Jakarta, \\ Indonesia
}

\section{Tyahya Whisnu Hendratni*}

Fakultas Ekonomi dan Bisnis, Universitas Pancasila, Jakarta, Indonesia

\begin{abstract}
This study aims to provide empirical evidence about the effect of DPK (Third Party Funds), CAR (Capital Adequacy Ratio), LDR (Loan to Deposit Ratio), and BOPO (Operating Expenses to Operating Income) on the profitability (ROA) of state banks. The multiple linear regression with classic assumption test was used to hypothesis testing. The results showed that DPK, LDR, and BOPO had a positive and significant effect on ROA, while CAR has no significantly effect. Among all the independent variables studied, DPK is the dominant variable affecting ROA, and, ROA can explained by the variables studied at $81.4 \%$ while the remainder was explained by other factors not included in the study.
\end{abstract}

\begin{abstract}
Abstrak
Penelitian ini bertujuan untuk memberikan bukti empiris tentang pengaruh DPK (Dana Pihak Ketiga), CAR (Capital Adequacy Ratio), LDR (Loan to Deposit Ratio), dan BOPO (Beban Operasional terhadap Pendapatan Operasional) terhadap profitabilitas (ROA) bank persero. Metode analisis yang digunakan adalah regresi linier berganda dengan uji asumsi klasik yang meliputi uji normalitas, uji multikolinieritas, uji heteroskedastisitas, dan uji autokorelasi. Hasil penelitian menunjukan bahwa variabel DPK, LDR, dan BOPO berpengaruh positif dan signifikan terhadap ROA bank persero. Sementara CAR tidak berpengaruh. Diantara semua variabel bebas yang diteliti, DPK menjadi variabel yang paling dominan mempengaruhi ROA. Pada penelitian ini ROA mampu dijelaskan oleh variabel yang diteliti sebesar $81.4 \%$ sedangkan sisanya dijelaskan oleh faktor - faktor lain yang tidak termasuk dalam penelitan.
\end{abstract}

*Email korespondensi: tyahyawhisnu@univpancasila.ac.id

Pedoman Sitasi: Parenrengi, S dan Hendratni, T.W. (2018). Pengaruh dana pihak ketiga, kecukupan modal dam penyaluran kredit terhadap profitabilitas bank. Jurnal Manajemen Strategi dan Aplikasi Bisnis, 1(1), 9 - 18
JMSAB

Paper type

Research paper

Keywords: DPK, CAR, LDR, BOPO, ROA

Received: 9 September 2018

Accepted: 16 November 2018

Online: 31 December

2018

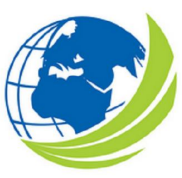

Jurnal Manajemen

Strategi dan Aplikasi

Bisnis, Vol 1, No.1,

Desember 2018,

pp. 9 - 18

eISSN 2655-237X 


\section{PENDAHULUAN}

Krisis global yang melanda Amerika Serikat pada tahun 2008 lalu telah menyebabkan kepanikan industri perbankan di seluruh dunia termasuk di Indonesia. Bahkan pemerintah Amerika serikat harus mengucurkan dana talangan bailout) sebesar US\$ 418 miliar untuk menyelamatkan perusahaan - perusahaan besar seperti General Motors, Citigroup Inc. dan American International Group Inc. (AIG) dari kebangkrutan. Krisis yang disebabkan kegagalan pada bisnis properti di Amerika Serikat atau lebih dikenal dengan sub-prime mortage ini bahkan secara tidak langsung masih berlanjut hingga sekarang di negara - negara Uni Eropa.

Sejak krisis tersebut, sektor perbankan telah mengalami transformasi besar di seluruh dunia dalam lingkungan operasinya. Sektor perbankan yang kuat mampu menghadapi kejutan negatif dan berkontribusi pada stabilitas dari sistem keuangan. Kinerja lembaga keuangan dipengaruhi oleh banyak faktor, di antara faktor-faktor ini adalah faktor internal dan eksternal yang berdampak langsung pada kinerja sektor perbankan (Almazari, 2014).

Faktor internal seperti keputusan manajemen, ukuran bank, modal, manajemen risiko dan manajemen biaya mempengaruhi profitabilitas bank secara langsung. Faktor internal lainnya, seperti kredit atau likuiditas dianggap sebagai faktor spesifik bank, yang terkait erat dengan manajemen bank, khususnya manajemen risiko. Kebutuhan akan risiko manajemen di sektor perbankan melekat dalam sifat bisnis perbankan. Rendahnya kualitas aset dan likuiditas merupakan dua penyebab utama kegagalan bank dan terwakili sebagai sumber risiko utama dalam hal risiko kredit dan likuiditas dan menarik perhatian besar dari para peneliti untuk memeriksa dampaknya terhadap profitabilitas bank.

Salah satu alat ukur profitabilitas bank adalah return on asset (ROA). Rasio ini merupakan ukuran kinerja profitabilitas bank karena ROA digunakan untuk mengukur efektifitas perusahaan didalam menghasilkan keuntungan dengan memanfaatkan aktiva yang dimilikinya. ROA merupakan rasio antara laba sebelum pajak terhadap total asset.

Studi mengenai faktor penentu profitabilitas bank telah banyak dilakukan, baik dalam konteks negara maju maupun negara berkembang. Beberapa riset terkini di Indonesia (seperti Sudarsono, 2017; Permatasari, 2017; Effendi, 2016; Anggreni dan Suardhika, 2014) menempatkan berbagai faktor sebagai determinan determinan profitabilitas. Meski demikian, hasil penelitian yang dilakukan masih berbeda. Sudarsono (2017) memberikan kesimpulan bahwa FIN dan BOPO berhubungan positif terhadap ROA, sedangkan DPK, TBH, FDR berhubungan negatif dan NPF tidak berpengaruh terhadap tingkat ROA. Penelitian Permatasari (2017) memberikan kesimpulan bahwa LDR, DPK dan NPL tidak memiliki pengaruh signifikan terhadap ROA. Hasil berbeda ditunjukkan oleh Anggreni dan Suardhika, (2014) yang membuktikan CAR memiliki pengaruh pengaruh positif, sedangkan NPL dan Suku Bunga berpengaruh negatif terhadap profitabilitas. Hasil serupa ditunjukkan oleh Effendi (2014) yang menunjukkan bahwa BOPO. NPF, CAR dan BI rate tidak memiliki pengaruh yang signifikan terhadap profitabilitas Bank.

Penelitian ini ditujukan untuk melakukan pengujian ulang pada pengaruh DPK (Dana Pihak Ketiga), CAR (Capital Adequacy Ratio), LDR (Loan to Deposit Ratio), dan BOPO (Beban Operasional terhadap Pendapatan Operasional) terhadap profitabilitas (ROA) bank persero. Hasil penelitian dapat memberikan kotribusi untuk menambah wawasan dan bukti empiris mengenai pengaruh DPK, CAR, LDR, dan BOPO terhadap profitabitas bank sehingga dapat dijadikan referensi yang bermanfaat bagi pemangku kepentingan untuk melakukan evaluasi terhadap faktor yang mempengaruhi profitabilitas bank di Indonesia.

\section{KAJIAN PUSTAKA}

Definisi Bank

Para ahli dalam bidang perbankan memberikan definisi yang berbeda-beda mengenai bank, namun demikian berbagai definisi tersebut mempunyai tujuan yang sama. Untuk memudahkan 
dalam mengartikan definisi tersebut, berikut beberapa pengertian bank menurut beberapa ahli, bank "Bank adalah lembaga keuangan yang kegiatan Utamanya adalah emnghimpun dana dari masyarakat dan menyalurkannya kembali dana tersebut ke masyarakat serta memberikan jasa lainnya" (Kasmir, 2012). Definisi lain oleh Lukman Dendawijaya (2003:25) disebutkan bahwa "Bank adalah suatu jenis lembaga keuangan yang melaksanakan berbagai macam jasa, seperti memberikan pinjaman, mengedarkan mata uang, pengawasan terhadap mata uang.

Berdasarkan Undang-Undang RI Nomor 10 Tahun 1998 tentang perbankan, perbankan disebutkan sebagai segala sesuatu yang menyangkut tentang bank, mencakup kelembagaan, kegiatan usaha, serta cara dan proses dalam melaksanakan kegiatan usahanya. Sedangkan bank adalah badan usaha yang menghimpun dana dari masyarakat dalam bentuk simpanan dan menyalurkannya kepada masyarakat dalam bentuk kredit dan atau bentuk-bentuk lainnya dalam rangka meningkatkan taraf hidup rakyat banyak. Kasmir (2012) menyebutkan bahwa usaha yang dilakukan disamping menyalurkan dana atau memberikan pinjaman (kredit) juga memberikan jasajasa keuangan dengan kegiatan menghimpun dana.

Jenis-jenis perbankan di Indonesia dapat ditinjau dari berbagai segi antara lain (Kasmir, 2014) dapat dikelompokkan menjadi jenis, kepemilikannya, status, dan prinsip. Dari jenisnya, menurut UU RI No.10 Tahun 1998 maka jenis perbankan terdiri dari: (1) Bank Umum, yaitu bank yang melaksanakan kegiatanusahanya secara konvensional dan atau berdasarkan prinsip syariah yang dalam kegiatannya memberikan jasa dalam lalu lintas pembayaran; dan (2) Bank Perkreditan Rakyat (BPR), yaitu bank yang melaksanakan kegiatan usaha secara konvensional atau berdasarkan prinsip syariah yang dalam kegiatannya tidak memberikan jasa dalam lalu-lintas pembayaran.

Kedua, dilihat dari segi kepemilikannya, bank dapat dikelompokkan menjadi empat, yaitu: (1) Bank Milik Pemerintah, merupakan bank yang akte pendirian maupun modalnya dimiliki oleh pemerintah, sehingga seluruh keuntungan bank ini dimiliki oleh pemerintah pula; (2) Bank Milik Swasta Nasional, merupakan bank yang seluruh atau sebagian besarnya dimiliki oleh swasta nasional serta akte pendiriannya pun didirikan oleh swasta, begitu pula bank-bank yang dimiliki oleh badan usaha yang berbentuk koperasi; (3) Bank milik asing, merupakan cabang dari bank yang ada diluar negeri, baik milik swasta asing maupun pemerintah suatu negara; dan (4) Bank Milik Campuran, merupakan bank yang kepemilikan sahamnya dimiliki oleh pihak asing dan pihak swasta nasional. Di mana kepemilikan sahamnya secara mayoritas dipegang oleh warga negara Indonesia.

Ketiga, dilihat dari segi statusnya, bank dikelompokkan menjadi: (1) Bank devisa, merupakan bank yang dapat melaksanakan transaksi keluar negeri atau yang berhubungan dengan mata uang asing secara keseluruhan; (2) Bank Non-Devisa, merupakan bank yang belum mempunyai izin untuk melaksanakan transaksi sebagai bank devisa, sehingga tidak dapat melaksanakan transaksi seperti halnya bank devisa.

Ke-empat, dilihat dari segi cara menentukan harga, bank dikelompokkan menjadi: (1) Bank berdasarkan prinsip konvensional, mayoritas bank yang beroperasi di Indonesia berdasarkan prinsip konvensional. Ciri khas prinsip konvensional antara lain menetapkan bunga sebagai harga jual untuk produk simpanan maupun pinjaman. Selain itu bank yang berdasarkan prinsip konvensional menetapkan biaya biaya dalam nominal atau presentase tertentu seperti biaya administrasi, sewa, atau biaya lainnya; (2) Bank berdasarkan prinsip syariah, yaitu bank berdasarkan prinsip syariah adalah bank yang menerapkan aturan perjanjian berdasarkan hukum Islam antar bank dengan pihak lain baik dalam hal untuk menyimpan dana atau pembiayaan usaha atau mencari keuntungan bagi bank berdasarkan prinsip syariah. 
Kerangka berpikir dan hipotesis

Kinerja bank merupakan ukuran keberhasilan bagi direksi bank tersebut, sehingga apabila kinerja itu buruk maka tidak mungkin para direksi ini akan diganti. Bank perlu dinilai kesehatannya, tujuannya adalah untuk mengetahui kondisi bank tersebut yang sesungguhnya apakah dalam keadaan sehat, kurang sehat, atau mungkin sakit. Apabila kondisi bank tersebut dalam kondisi sehat, maka perlu dipertahankan kesehatannya. Akan tetapi jika kondisinya dalam keadaan tidak sehat maka segera perlu diambil tindakan untuk mengobatinya (Kasmir, 2012).

Ratio Profitabilitas merupakan rasio yang digunakan untuk mengukur kemampuan perusahaan dalam memperoleh laba atau keuntungan, profitabilitas suatu perusahaan mewujudkan perbandingan antara laba dengan aktiva atau modal yang menghasilkan laba tersebut. Rentabilitas (Profitabilitas), merupakan kemampuan perusahaan dalam menciptakan laba atau keuntungan Return On Assets (ROA) merupakan rasio yang digunakan untuk mengukur kemampuan manajemen Bank dalam memperoleh profitabilitas dan mengelola tingkat efisiensi usaha bank secara keseluruhan. Semakin besar nilai rasio ini menunjukkan tingkat rentabilitas usaha bank semakin baik atau sehat. Rasio ini dapat dijadikan sebagai ukuran kesehatan keuangan. Rasio ini sangat penting, mengingat keuntungan yang diperoleh dari penggunaan aset dapat mencerminkan tingkat efisiensi usaha suatu bank. Dalam kerangka penilaian kesehatan bank, BI akan memberikan score maksimal 100 (sehat) apabila bank memiliki ROA > 1,5\%. Semakin besar Return On Assets (ROA) suatu Bank, semakin besar pula tingkat keuntungan yang dicapai bank tersebut dan semakin baik pula posisi bank tersebut dari segi penggunaan asset.

Hubungan DPK dengan profitabiltas

Dana pihak ketiga (DPK) merupakan dana yang bersumber dari masyarakat luas merupakan sumber penting untuk aktivitas operasional bank dan merupakan tolak ukur keberhasilan suatu bank apabila bank dapat menanggung biaya operasinya dari sumber dana ini (Kasmir, 201). Jika DPK meningkat maka bank mempunyai peluang serta kesempatan yang lebih besar untuk memperoleh pendapatan yang lebih tinggi. Oleh karena itu, DPK diasumsikan memiliki hubungan positif terhadap profitabilitas. Hal ini mengindikasikan bahwa semakin banyak simpanan nasabah yang dihimpun bank persero maka akan meningkatkan kegiatan usaha bank untuk memperoleh profitabilitasnya. Sehingga bank diharapkan mampu mendorong nasabah untuk meningkatkan simpanannya agar dapat memaksimalkan profitabilitasnya dengan menjaga spread antara bunga simpanan dan bunga kredit serta menjaga agar dana tidak idle Dengan semakin banyak dana yang dapat dihimpun melalui dana pihak ketiga maka bank dapat menambah kredit atau kegiatan usaha lainnya yang dapat mendatangkan profitabilitas yang lebih besar bagi bank. Oleh karena itu bank dituntut kreatif untuk mengembangkan produk - produk yang menarik dan sesuai dengan kebutuhan nasabah guna menambah dana pihak ketiga yang dihimpun oleh bank.

Sejalan dengan itu, Sudiyanto (2010) yang meneliti DPK menggunakan data time series pada sampel bank yang listing di BEI dan menyimpulkan Dana Pihak Ketiga memiliki pengaruh signifikan terhadap profitabilitas bank. Sementara Nasution (2011), Anggreni dan Suardika (2014), dan Permatasari (2017) yang melakukan penelitian terhadap bank persero di Indonesia juga menghasilkan temuan bahwa Dana Pihak Ketiga berpengaruh positif dan signifikan terhadap ROA.

$\mathrm{H}_{1}$ : Dana pihak ketiga (DPK) berpengaruh signifikan terhadap profitabilitas (ROA) 
Hubungan CAR dengan profitabiltas

Capital Adequacy Ratio (CAR) merupakan aspek kecukupan permodalan bank yang memperlihatkan kemampuan manajemen bank untuk mengawasi serta mengontrol risiko yang terjadi, yang bisa mempengaruhi besarnya modal bank. Bank yang mempunyai modal yang memadai maka dapat melakukan kegiatan operasionalnya dengan efisien, dan akan memberikan keuntungan pada bank tersebut. CAR di atas $8 \%$ menunjukkan usaha bank yang semakin stabil, karena adanya kepercayaan masyarakat yang besar. Dapat diasumsikan bahwa kecukupan modal (CAR) berpengaruh positif terhadap porofitabilitas. Sejalan dengan penjelasan di atas, Anggreni dan Suardika (2014) memberikan kesimpulan bahwa CAR berpengaruh positif terhadap profitabilitas.

$\mathrm{H}_{2}$ : Capital Adequacy Ratio (CAR) berpengaruh signifikan terhadap profitabilitas (ROA)

Hubungan LDR dengan profitabiltas

Loan To Deposit Ratio (LDR) merupakan rasio kredit yang diberikan terhadap dana pihak ketiga (Giro, Tabungan, Sertifikat Deposito, dan Deposito). LDR menurut S.E. Intern Bank Indonesia (2004) merupakan Penilaian aspek likuiditas mencerminkan kemampuan bank untuk mengelola tingkat likuiditas yang memadai guna memenuhi kewajibannya secara tepat aktu dan untuk memenuhi kebutuhan yang lain. Rasio LDR merupakan ukuran likuiditas yang mengukur perbandingan dana yang ditempatkan dalam bentuk kredit, yang berasal dari dana pihak ketiga. Semakin tinggi rasio LDR menunjukkan tingginya dana yang telah disalurkan dibandingkan dengan dana pihak ketiga yang berada di bank. Dapat disimpulkan bahwa semakin besar rasio LDR, maka semakin besar pendapatan kredit yang diterima bank yang kemudian berdampak terhadap semakin tingginya rasio ROA. Hal tersebut berarti rasio LDR berpengaruh positif terhadap rasio ROA. Sejalan dengan asumsi tersebut, Permatasari (2017) memberikan kesimpulan bahwa LDR berpengaruh positif terhadap profitabilitas.

$\mathrm{H}_{3}$ : Loan To Deposit Ratio (LDR) berpengaruh signifikan terhadap profitabilitas (ROA)

Hubungan BOPO dengan profitabilitas

BOPO atau Belanja Operasional terhadap Pendapatan Operasional merupakan rasio yang menggambarkan efisiensi perbankan dalam melakukan kegiatannya. Belanja operasional adalah biaya bunga yang diberikan pada nasabah sedangkan pendapatan operasional adalah bunga yang didapatkan dari nasabah. Semakin kecil nilai BOPO artinya semakin efisien perbankan dalam beroperasi. Dengan kata lain, apabila BOPO meningkat menunjukkan kemampuan bank untuk menghasilkan pendapatan menurun dan menurunya pendapatan berpengaruh terhadap turunnya rasio pendapatan terhadap aset bank.

Sejalan uraian di atas, Mahardian (2008) yang meneliti tentang variabel yang mempengaruhi Profitabilitas pada 20 bank devisa di Indonesia yang menggunakan data laporan keuangan triwulan yang menyimpulkan bahwa efisiensi operasi diproksikan dengan rasio BOPO memiliki pengaruh signifikan terhadap profitabilitas bank, penelitian serupa yang dilakukan oleh Buyung (2009) yang melakukan penelitian terhadap 81 bank juga menghasilkan temuan bahwa semakin berkurangnya beban operasional berpengaruh signifikan terhadap peningkatan ROA bank. Penelitian lebih baru seperti Avrita dan Pangestuti $(2016)$ dan Effendi $(2016,2018)$ juga membuktikan adanya hubungan signifikan antara BOPO dan profitabilitas.

$\mathrm{H}_{1}$ : BOPO berpengaruh signifikan terhadap profitabilitas ( $\mathrm{ROA}$ )

\section{METODE PENELITIAN}

Ruang Lingkup Penelitian

Penelitian ini dilakukan untuk menguji apakah variabel bebas yang terdiri dari Dana Pihak Ketiga (DPK), Capital Adequacy Ratio (CAR), Loan toDeposit Ratio (LDR), mempengaruhi variabel terikat 
yaitu profitabilitas pada bank persero yang diproksikan dengan rasio Return on Assets (ROA). Jangka waktu penelitian dilakukan mulai Januari 2014 sampai dengan Desember 2017.

Populasi dan Sampel

Populasi dalam penelitian ini adalah bank umum di Indonesia yang yang melaporkan kinerjanya pada Bank Indonesia yang terdiri dari 120 bank. Sementara metode penentuan sampel yang digunakan dalam penelitian ini menggunakan metode purposive sampling. Metode purposive sampling adalah teknik penentuan sampel yang satuan sampelnya dipilih berdasarkan pertimbangan tertentu dengan tujuan untuk memperoleh satuan sampel yang memiliki karakteristik dan kriteria yang dikehendaki dalam pengambilan sampel (Suryani dan Hendryadi, 2015), dengan demikian ukuran sampel yang digunakan dalam penelitian ini terdiri dari 4 bank yang dapat dilihat pada tabel dibawah ini :

Tabel 1. Sampel Penelitian

\begin{tabular}{|c|l|c|}
\hline No & \multicolumn{1}{|c|}{ Nama Bank } & \multicolumn{1}{|c|}{ Kode } \\
\hline 1 & PT Bank Mandiri Tbk. & BMRI \\
\hline 2 & PT Bank Rakyat Indonesia Tbk. & BBRI \\
\hline 3 & PT Bank Negara Indonesia 46 Tbk. & BBNI \\
\hline 4 & PT Bank Tabungan Negara Tbk. & BBTN \\
\hline
\end{tabular}

Pengukuran Variabel

Dalam penelitian ini terdapat 4 variabel bebas yang akan digunakan yaitu: Dana Pihak Ketiga (X1) yang merupakan proksi dari simpanan nasabah, Capital Adequacy Ratio (X2) yang merupakan proksi dari kecukupan modal, Loan to Deposit Ratio (X3 yang merupakan proksi dari penyaluran kredit, dan Beban Operasional terhadap Pendapatan Operasional (X4) yang merupakan proksi dari efisiensi operasi. Sementara variabel terikat yang digunakan dalam penelitian ini adalah Return of Assets (Y) yang mewakili indikator profitabilitas.

\section{Tabel 2. Operasionalisasi Variabel}

\begin{tabular}{|c|l|l|}
\hline No & Variabel & \multicolumn{1}{c|}{ Kode } \\
\hline 1 & Dana Pihak Ketiga (DPK) & DPK = Dana pihak ketiga / total kewajiban x 100 \\
\hline 2 & Capital Adequacy Ratio (CAR) & CAR = Modal / Aset tertimbang menurut resiko x 100 \\
\hline 3 & Loan to Deposit Ratio (LDR) & LDR = total kredit bukan bank / total DPK x 100 \\
\hline 4 & $\begin{array}{l}\text { Beban Operasional terhadap } \\
\text { Pendapatan Operasional } \\
\text { (BOPO) }\end{array}$ & BOPO = belanja operasional / pendapatan operasional x 100 \\
\hline 5 & Return on asset (ROA) & ROA = laba sebelum pajak / rata-rata total asset x 100 \\
\hline
\end{tabular}

Teknik Analisis

Teknik analisis yang digunakan untuk menganalisis data adalah analisis regresi linier berganda (multiple linier regression method) yang bertujuan untuk menguji pengaruh dan hubungan lebih dari satu variabel bebas terhadap variabel terikat.Pada awalnya analisis regresi berganda dikembangkan oleh para ahli ekonometri untuk membantu meramal akibat dari aktivitas - aktivitas ekonomi pada berbagai segmen ekonomi. 
Jurnal Manajemen Strategi dan Aplikasi Bisnis, 1(1), 9-18

Parenrengi, S., \& Hendratni, T.W. Pengaruh dana pihak ketiga..

\section{HASIL DAN PEMBAHASAN}

Sebelum melakukan analisis regresi berganda, sebuah model regresi harus melewati serangkaian uji asumsi klasik. Uji asumsi klasik bertujuan agar hasil analisis regresi berganda memenuhi kriteria BLUE (Best Linear Unbiased Estimate) yaitu data terdistribusi normal, tidak terdapat gejala autokorelasi, tidak terdapat multikolinieritas, dan tidak terdapat heterokedastisitas. Hasil penelitian memberikan kesimpulan bahwa seluruh asumsi terpenuhi sehingga analisis regresi linier berganda dapat diinterpretasi.

\section{Analisis regresi linier berganda}

Koefisien korelasi (adjusted $R^{2}$ ) menunjukka n seberapa besar korelasi atau hubungan antara variabel-variabel bebas dengan variabel terikat (Ghozali, 2016). Uji ini bertujuan untuk menentukan proporsi atau presentase total variansi dalam variabel terikat yang diterangkan oleh variabel bebas. Apabila yang digunakan adalah regresi sederhana, maka nilai yang digunakan adalah nilai R Square. Namun, apabila analisis yang digunakan adalah regresi berganda, maka yang digunakan adalah Adjusted $R$ Square. Hasil perhitungan Adjusted $R$ Square dapat dilihat pada output Model Summary. Koefisien determinasi $\left(\mathrm{R}^{2}\right)$ merujuk kepada Ghozali (2016), apabila model regresi terdapat lebih dari 1 variabel bebas, maka uji koefisien determinasi menggunakan determinasi adjusted $R^{2}$. Pada tampilan output SPSS model summary, nilai koefisien korelasi Adjusted $R$ Square atau koefisien determinasi adalah 0,816. Hal ini berarti $81,6 \%$ variasi atau perubahan dalam variabel terikat dapat dijelaskan oleh variable bebas, sedangkan 19,4\% sisanya dijelaskan oleh faktor-faktor lain di luar model penelitian.

Hasil uji ANOVA atau uji $\mathrm{F}$ tersebut, $\mathrm{F}$ hitung sebesar 70,715 adapun $\mathrm{F}$ tabel dengan tingkat signifikansi 5\% diperoleh $\mathrm{F}$ tabel sebesar 2,960. Dalam hal ini makan F hitung $>\mathrm{F}$ tabel yaitu 70,715 > 2,960. Selain itu dari tabel ANOVA dapat dilihat besar probabilitas yaitu 0,001. Karena signifikan penelitian kurang dari 0,05 yaitu $0,001<0,05$ maka ada pengaruh yang signifikan antara profitabilitas, pertumbuhan pejualan, dan pertumbuhan aset terhadap struktur modal secara simultan (bersama-sama).

Tabel 3. Hasil regresi

\begin{tabular}{lrrrl}
\hline Variabel & Koefisien & t-hitung & sig & Kesimpulan \\
\hline (Constant) & 647.282 & 3.192 & 0.002 & \\
DPK & 0.000 & 3.399 & 0.001 & Signifikan \\
CAR & 0.065 & .1 .792 & 0.078 & Tidak signifikan \\
LDR & 0.021 & 4.223 & 0.000 & Signifikan \\
BOPO & 0.071 & .4 .106 & 0.000 & Signifikan \\
\hline Adj.R & 0.816 & & & \\
F-statistik & & 70.715 & 0.001 & Signifikan \\
& & & &
\end{tabular}

Sumber: data diolah

Persamaan regresi tersebut di atas dapat di interpretasikan sebagai berikut: pertama, Konstanta bernilai $647.282 \mathrm{X}$ menunjukkan bahwa jika tidak ada pengaruh variabel terikat, yaitu, DPK, CAR,LDR dan Bopo terhadap ROA, maka ROA akan tetap sebesar 647.282X.

Dana pihak ketiga bernilai $4.832 \%$ menyatakan bahwa setiap kali terjadi kenaikan 1\% ROA, maka akan mendorong kenaikan Dana pihak ketiga sebesar $4.832 \%$. Dengan asumsi variabel lain tetap (variabel lain sama dengan nol). Hasil uji regresi berganda yang menunjukan Dana pihak ketiga $\left(\mathrm{X}_{1}\right)$ memiliki pengaruh positif dan tidak signifikan terhadap Return of aset (Y). Hasil, t hitung 3,399 dengan sig.0,002. Nilai signifikansi profitabilitas lebih besar dari signifikansi yang diharapkan 
$(0,05)$ menunjukkan bahwa variabel return on assets berpengaruh positif Hal ini diperkuat dengan melihat nilai Sig. Hasil penelitian ini konsisten Nasution (2011), Anggreni dan Suardika (2014), dan Permatasari (2017) yang melakukan penelitian terhadap bank di Indonesia juga menghasilkan temuan bahwa Dana Pihak Ketiga berpengaruh positif dan signifikan terhadap ROA. Hal ini mengindikasikan bahwa semakin banyak simpanan nasabah yang dihimpun bank persero maka akan meningkatkan kegiatan usaha bank untuk memperoleh profitabilitasnya. Sehingga bank diharapkan mampu mendorong nasabah untuk meningkatkan simpanannya agar dapat memaksimalkan profitabilitasnya dengan menjaga spread antara bunga simpanan dan bunga kredit serta menjaga agar dana tidak idle Dengan semakin banyak dana yang dapat dihimpun melalui dana pihak ketiga maka bank dapat menambah kredit atau kegiatan usaha lainnya yang dapat mendatangkan profitabilitas yang lebih besar bagi bank. Oleh karena itu bank dituntut kreatif untuk mengembangkan produk - produk yang menarik dan sesuai dengan kebutuhan nasabah guna menambah dana pihak ketiga yang dihimpun oleh bank.

CAR memiliki nilai koefisien sebesar 0.65 sehingga setiap kali terjadi kenaikan 1\% ROA, maka akan mendorong kenaikan CAR sebesar 0.65\%. Dengan asumsi variabel lain tetap (variabel lain sama dengan nol). Hasil uji regresi berganda yang menunjukan Capital Adequacy Ratio $\left(\mathrm{X}_{2}\right)$ memiliki pengaruh positif dan tidak signifikan terhadap Return of aset $(\mathrm{Y})$. Hasil, $\mathrm{t}$ hitung 1,792 dengan sig.0,078. Nilai signifikansi profitabilitas lebih besar dari signifikansi yang diharapkan $(0,05)$ menunjukkan bahwa variabel return on assets berpengaruh positif namun tidak signifikan. Hasil penelitian berbeda dengan penelitian sebelumnya yang dilakukan Anggreni dan Suardika (2014). Hal ini diduga bahwa bank sebagai intermediary institution yang kegiatan usaha utamanya menghimpun dana dalam bentuk tabungan, giro, dan deposito serta menyalurkan kembali dalam bentuk kredit. Sehingga besar kecilnya keuntungan yang diperoleh berdasarkan besar - kecilnya dana yang berhasil dihimpun dan disalurkan kembali untuk mendapatkan spread, bukan seperti kegiatan usaha non bank yang sangat mengandalkan capital yang dimiliki untuk memperoleh keuntungan Selain itu kebijakan pemerintah yang mengatur kewajiban penyediaan modal minimum juga berpotensi mengurangi profitabilitas bank dikarenakan dana yang seharusnya dapat digunakan untuk kegiatan usaha seperti meningkatkan kredit atau transaksi valuta asing harus dibatasi guna memenuhi kewajiban CAR sebesar 8\%.

LDR memiliki nilai koefisien sebesar 0.21 , sehingga dapat dinyatakan bahwa setiap kali terjadi kenaikan 1\% ROA, maka akan mendorong kenaikan CAR sebesar 0.21\%. Dengan asumsi variabel lain tetap (variabel lain sama dengan nol). Hasil uji regresi berganda yang menunjukan bahwa Loan to Deposit Ratio (LDR) (X $\mathrm{X}_{3}$ memiliki pengaruh positif terhadap ROA (Y). Hasil, t hitung 4,223 dengan sig.0,000 sehingga dapat disimpulkan terdapat pengaruh yang signifikan antara variabel LDR terhadap variabel terikat. Hasil tersebut sesuai dengan hipotesis alternatif ketiga (H3) yang menyatakan bahwa Loan to Deposit Ratio (LDR) berpengaruh positif dan signifikan terhadap Return On Assets (ROA). Penelitian ini konsisten dengan penelitian sebelumnya yang dilakukan oleh Puspitasari (2009) yang menyimpulkan bahwa kredit diproksikan dengan LDR memiliki pengaruh signifikan terhadap profitabilitas bank. Hal ini mengindikasikan bahwa semakin tinggi kredit yang disalurkan oleh bank persero maka profitabilitas yang dihasilkan akan semakin meningkat. Hal ini sesuai dengan kegiatan utama bank sebagai lembaga perantara keuangan (financial intermediary institution) dimana jumlah kredit yang disalurkan merupakan sumber pendapatan utama bank. Sehingga bank diharapkan meningkatkan kredit yang disalurkan dengan mempertimbangankan aspek analisis kredit guna meminimalisir resiko gagal bayar (default) yang dapat mengurangi profitabilitas bank.

Variabel BOPO memiliki nilai koefisien 0.71 sehingga dapat dinyatakan bahwa setiap kali terjadi kenaikan 1\% ROA, maka akan mendorong kenaikan BOPO sebesar 0.71\%. Dengan asumsi variabel lain tetap (variabel lain sama dengan nol). Hasil uji regresi berganda yang menunjukan bahwa Beban Operasional terhadap Pendapatan Operasional (BOPO) $\left(\mathrm{X}_{4}\right)$ memiliki pengaruh positif 
terhadap retrun of asets (Y). Hasil, t hitung 4,106 dengan sig.0,000. Hasil tersebut sesuai dengan hipotesis alternatif keempat (H4) yang menyatakan bahwa Beban Operasional terhadap Pendapatan Operasional (BOPO) berpengaruh negatif dan signifikan terhadap Return On Assets (ROA). Hasil penelitian ini konsisten dengan penelitian sebelumnya yang dilakukan oleh Mahardian (2008) yang membuktikan pengaruh BOPO signifikan terhadap profitabilitas bank, penelitian serupa yang dilakukan oleh Avrita dan Pangestuti (2016) dan Effendi (2016, 2018) juga membuktikan adanya hubungan signifikan antara BOPO dan profitabilitas.

\section{KESIMPULAN}

Kesimpulan

Hasil penelitian memunjukan bahwa variabel DPK (Dana Pihak Ketiga) berpengaruh positif dan signifikan terhadap ROA (Return On Assets). Variabel CAR (Capital Adequacy ratio) berpengaruh positif dan tidak signifikan terhadap ROA. Variabel LDR (Loan to Deposit Ratio) berpengaruh positif dan signifikan terhadap ROA, dan BOPO (Beban Operasional terhadap Pendapatan Operasional) berpengaruh signifikan terhadap ROA. Dari semua variabel bebas yang diteliti, variabel yang paling dominan mempengaruhi ROA adalah variabel LDR (Loan to Deposit Ratio).

Implikasi

Hasil penelitian ini yang menyimpulkan bahwa Dana Pihak Ketiga (DPK), Loan to Deposit ratio (LDR), dan Beban Operasional terhadap Pendapatan Operasional (BOPO) berpengaruh positif dan signifikan terhadap ROA (Return On Assets). Diharapkan bagi industri perbankan yang ada di Indonesia khususnya bagi bank persero untuk meningkatkan simpanan nasabah, serta penyaluran kredit. Selain itu bank juga harus meningkatkan efisiensi operasi dengan cara mengurangi beban operasional untuk meningkatkan profitabilitas bank. Loan Dept Ratio (LDR) merupakan variabel yang paling berpengaruh terhadap profitabilitas bank persero, oleh karena itu bagi industri perbankan di Indonesia diharapkan mendorong nasabah untuk meningkatkan simpanannya di bank sebagai prioritas utama seperti meningkatkan pelayanan produk simpanan, atau memberikan hadiah khusus kepada nasabah yang mau menyimpan dananya di bank dalam jumlah besar agar bank dapat memperoleh keuntungan maksimal

Keterbatasan

Penelitian ini hanya menggunakan 4 variabel bebas, diharapkan bagi akademisi yang akan melakukan penelitian selanjutnya menambah variabel - variabel lain seperti: rasio - rasio lainnya (PDN, GWM, CKPN) , faktor ekonomi secara makro (Inflasi, nilai kurs, PDB) , serta faktor resikometode yang digunakan pada penelitian ini menggunakan analisis regresi berganda, diharapkan bagi akademisi yang akan melakukan penelitian selanjutnya menggunakan metode lainnya seperti analisis jalur (path analysis), atau SEM (Structural Equation Model), atau menambah jangka waktu penelitian agar didapat hasil yang lebih akurat.

\section{REFERENSI}

Ali, M, (2004). Asset Liability Management: Menyiasati Risiko Pasar dan Risiko Operasional, Jakarta, PT. Gramedia.

Anggreni, M. R., \& Suardhika, M. S. (2014). Pengaruh Dana Pihak Ketiga, Kecukupan Modal, Risiko Kredit Dan Suku Bunga Kredit Terhadap Profitabilitas Bank Bumn Tahun 2010-2012. E-Jurnal Akuntansi, 27-37.

Avrita, R. D., \& Pangestuti, I. R. D. (2016). Analisis Pengaruh CAR, NPL, LDR, NIM, dan BOPO Terhadap Profitabilitas Bank (Perbandingan Bank Umum Go Public Dan Bank Umum Non Go Public Di Indonesia Periode Tahun 2011-2014). Diponegoro Journal of Management, 5(2), 366-378. 
Effendi, E. Y. (2016). Pengaruh Rasio Keuangan Dan Variabel Makro Ekonomi Terhadap Kondisi Profitabilitas Bank Muamalat Indonesia Tahun 2004-2014. Perbanas Review, 2(1).

Effendi, E. Y. (2018). Pengaruh Rasio Keuangan Dan Variabel Makro Ekonomi Terhadap Kondisi Profitabilitas Bank Muamalat Indonesia. Perbanas Review, 3(1).

Ghozali, Imam, (2016). Aplikasi Analisis Multivariate dengan Program SPSS 19, Semarang, Badan Penerbit Universitas Diponegoro

Kasmir, (2014). Bank dan Lembaga Keuangan Lainnya, Jakarta, PT. Rajawali Press

Martono, (2010). Bank dan Lembaga Keuangan Lain, EKONOSIA Fakultas Ekonomi UII, Yogyakarta

Mahardia, P. (2008). Analisis pengaruh rasio CAR, BOPO, NPL, NIM dan LDR terhadap kinerja keuangan perbankan (studi kasus perusahaan perbankan yang tercatat di bej periode juni 2002 â juni 2007) (Doctoral dissertation, Program Pascasarjana Universitas Diponegoro).

Nasution, Masnindar, (2012). Pengaruh Dana Pihak Ketiga (DPK), Non Performing Financing (NPF), Dan Nisbah Bagi Hasil Terhadap Laba Pada Bank Syariah Di Indonesia (Periode 2003-2012), Skripsi Fakultas Ekonomidan Bisnis UIN Syarif Hidayatullah, Jakarta, 2012.

Permatasari, A. K. M., \& Amboningtyas, D. (2017). The Influence of LDR, DPK, and NPL on ROA through CAR as Intervening Variable (Study on Conventional Bank Sub Sector Company 20122016 listed in BEI). Journal of Management, 3(3).

Sudarsono, H. (2017). Analisis Pengaruh Kinerja Keuangan terhadap Profitabilitas Bank Syariah di Indonesia. Economica: Jurnal Ekonomi Islam, 8(2), 175-203.

Surat Edaran Bank Indonesia No.6/23/DPNP Tanggal 31 Mei 2004 tentang Tata Cara Penilaian Kesehatan Bank

Suryani, dan Hendryadi. (2015). Metode Riset Kuantitatif: Teori dan Aplikasi pada Penelitian Bidang Manajemen dan Ekonomi Islam. Jakarta, Predanamedia Group

\section{PROFIL PENULIS}

Sudarmin Parenrengi, dosen Tetap Fakultas Ekonomi dan Bisnis Universitas Pancasila. Saat ini Mengampu Mata Kuliah Manajemen Keuangan , Pengantar Manajemen dan Teori Mikro. Pendidikan S3 ( Doktoral ) ditempuh di IPB ( Institut Pertanian Bogor). Saat ini Penulis lebih tertarik melakukan penelitian dalam bidang Keuangan.

Tyahya Whisnu Hendratni, dosen Tetap Fakultas Ekonomi dan Bisnis Universitas Pancasila. Mengajar sejak tahun 2001. Telah Mengampu mata kuliah : Pasar modal, manajemen Keuangan, Manajemen Distribusi, Manajemen Pemasaran, Manajemen Produk dan Harga, Pengantar Bisnis, etika Bisnis, Kewirausahaan, Manajemen Pemasaran Jasa, Pemasaran Relasional dan Komunikasi Bisnis. Riwayat Pendidikan S1, S2 dan S3 adalah Konsentrasi Manajemen Keuangan sehingga sekarang lebih tertarik menulis berkaitan dengan penelitian dalam bidang keuangan. Email : tyahyawhisnu@univpancasila.ac.id 